\title{
GC-MS analysis of yellow pigmented Macrococcus equipercicus isolated from alfalfa rhizosphere soil fields of Coimbatore
}

\author{
Z. Aiysha Thasneem \\ Department of Microbiology, Karpagam Academy of Higher Education, Coimbatore- \\ 641021, Tamil Nadu, INDIA \\ K. Aravindh \\ Department of Microbiology, Karpagam Academy of Higher Education, Coimbatore- \\ 641021, Tamil Nadu, INDIA \\ M. Jeba Malar Fencia \\ Department of Microbiology, Karpagam Academy of Higher Education, Coimbatore- \\ 641021, Tamil Nadu, INDIA \\ C. Nitheesh Kumar \\ Department of Microbiology, Karpagam Academy of Higher Education, Coimbatore- \\ 641021, Tamil Nadu, INDIA

\section{T. Pavithra} \\ Department of Microbiology, Karpagam Academy of Higher Education, Coimbatore- \\ 641021, Tamil Nadu, INDIA

\section{K. Rajkumar} \\ Department of Microbiology, Karpagam Academy of Higher Education, Coimbatore- \\ 641021, Tamil Nadu, INDIA
}

S. Surendran

Department of Microbiology, Karpagam Academy of Higher Education, Coimbatore641021, Tamil Nadu, INDIA

\section{Vidhya}

Department of Microbiology, Karpagam Academy of Higher Education, Coimbatore641021, Tamil Nadu, INDIA

\section{R. Mahesh}

PG and Research Centre of Botany, South Travancore Hindu College, Nagercoil-629002, Kanyakumari District (Tamil Nadu), India

\section{S. Ramalakshmi*}

Department of Microbiology, Sri Moogambigai Arts and Science College for Women, Palacode-Hosur Main Road, Thimmarayanahalli PO, Mallupatti, Dharmapuri Dst.-636805, (Tamilnadu), India

*Corresponding author. E-mail: arulaksh24@gmail.com

\section{Abstract}

The rhizosphere of plant possesses important microflora, which secretes wide chemical compounds including secondary metabolites necessary for plant growth and development. The microbial flora of alfalfa plant rhizosphere soil region was explored for functional activity and we found upto ten different pigmented colonies. Due to good functional diversity, this yellow pigmented colony was taken for further studies. Thus, the culture was molecularly characterized and identified for potent bioactive components responsible for antimicrobial activity. The selected culture mass was cultured and secondary metabolites were produced and extracted using ethyl acetate and subjected to GC-MS analysis. The antimicrobial study revealed selective activity against Streptococcus pneumonia, and Proteus $s p$ with zone of inhibition to be 18 and $20 \mathrm{~mm}$ respectively. Molecular identification of the isolate by $16 \mathrm{~S}$ rRNA sequencing showed the isolate as Macrococcus equipercicus with $100 \%$ similarity. Based on GC-MS analysis report 25bioactive compounds were identified and 13-docosenamide, hexadecanoic acid esters and quercetin were found in ethyl acetate extract. Conclusion: Thus the yellow pigmented gram positive cocci M.equipercicus isolated from Medicago sativa possessed wide antibacterial activity due to presence of quercetin. Through the studies, we were able to identify potent antibacterial compound producing bacteria from $M$. sativa plant rhizosphere soil.

Keywords: Alfalfa plant, gas chromatography-mass spectrometry, Macrococcus equipercicus, Medicago sativa, Rhizosphere

\section{INTRODUCTION}

Alfalfa plant also known as Medicago sativa pos-

\section{Article Info}

https://doi.org/10.31018/

jans.v11i3.2139

Received: July 2, 2019

Revised: August 16, 2019

Accepted: August 26, 2019

\section{How to Cite}

Thasneem, Z. A. et al. (2019). GC-MS analysis of yellow pigmented Macrococcus equipercicus isolated from alfalfa rhizosphere soil fields of Coimbatore. Journal of Applied and Natural Science, 11(3): 645- 649 https:// doi.org/10.31018/ jans.v11i3.2139 
to pharmacological importance due to the variety of compounds that has been isolated and identified to cure a variety of diseases (atherosclerosis, heart disease, stroke, cancer, diabetes) (Zhang et al., 2006; Bora and Anupam, 2011; Krakowska et al., 2017). They are also cultivated worldwide for high protein and fiber for cows. Macrococcus sp belongs to family Staphylococcaceae are gram positive cocci, non-motile and non-spore forming (Becker et al., 2014).

Studies conducted in our lab showed that alfalfa plant rhizosphere soil contains Bacillus horikoshii (Nisha et al., 2019a) and Pantoeaagglomerans (Nisha et al., 2019b) with wide antibacterial activities. Macrococcusluteus and Neisseria sicca has been reported to be isolated from soil of Calotropisprocera and Catharanthusroseus. Their extracts possessed antibacterial activities against pathogens (Arora et al., 2013). Upon preliminary screening of microbes isolated from rhizosphere soil region of alfalfa plant, this isolate was selected for its amylase, cellulase, protease and phosphate solubilization activities. Therefore, the study was aimed to study the antibacterial activity, culture, extract and identify bioactive compounds of functionally diverse organism from rhizosphere soil region of Alfalfa plant ( $M$. sativa) through GCMS.

\section{MATERIALS AND METHODS}

Sample collection: The rhizosphere region soil samples of Alfalfa (Medicago sativa) plant were collected from June 2016 to March 2017 at Sulur, Coimbatore, Tamilnadu, India.

Isolation and antibacterial activity: Spread plate method was employed for isolation of microbes from the rhizosphere soil by taking one gram of the collected soil samplesfor serial dilution. About $0.1 \mathrm{ml}$ of serially diluted samples $\left(10^{-1}\right.$ to $10^{-7}$ ) was spreaded onto sterile plates and incubated at $37^{\circ} \mathrm{C}$ for $24-72$ hours. The isolated colonies were selected and stored in glycerol stocks until further required. The colonies were characterized by staining and biochemical standard methods. The selected isolates were studied for their antimicrobial activities against bacterial pathogens by well diffusion method (Nisha et al., 2019a).

Production and extraction of the bioactive compounds: The bioactive compounds were extracted from the culture by large scale cultivation of microbes. After growth, the cells are separated by centrifugation and the supernatant is taken for for extraction process. Ethyl acetate was chosen as solvent for solvent to extract the compounds. After extraction, the solvent were evaporated to collect residues and stored and studied for GCMS (Nisha et al., 2019b).

GC-MS analysis: The microbial extract was further subjected to GC-MS analysis using Thermo
MS DSQ II packed DB 35- MS Capillary standard non- polar column. Further the isolated compounds mass spectrums were interpretated by known compounds database NIST.

Molecular identification and phylogenetic analysis: The bacterial genomic DNA isolation were carried out using standard cold spring harbour lab protocol. From the isolated genomic DNA, rRNA genes (1.4 kb length gene)were amplified using the $8 \mathrm{~F}$ and $1541 \mathrm{R}$ universal eubacterial primers (5`-AGAGTTTGATCCTGGCTCAG-3` and 5`AAGGAGGTGATCCAGCCGCA $-3^{\prime}$ as forward and reverse primers). After amplification, the PCR products were sequenced by big dye terminator cycle sequencing kit (Applied BioSystems, USA) and resolved using Applied Biosystems model 3730XL automated DNA sequencing system (Xcelris Laboratories, India). The phylogeny analyses with multiple closely related sequences were done using MUSCLE 3.7 and PhyML 3.0 aLRT (Nisha et al., 2019a and b).

\section{RESULTS AND DISCUSSION}

Antibacterial activity: The plant usually releases a variety of carbon and other important nutrients necessary for microbial growth, which makes the mutualistic relationship between plants and microbes at rhizosphere interface (Bertin et al., 2003). The microbial extract of yellow pigmented colony studied for antibacterial activity against 7 clinical pathogens namely P.aeruginosa, Klebsiella $s p$, S. aureus, Proteus vulgaricus, S. pneumonia, E. coli, B. cereusrevealed that significant zone of inhibition was against against Streptococcus pneumonia and Proteus sp (18 and 20 mmrespectively) (Fig. 1). Similar to our study results, Janani et al., (2014) studied the pigmented marine bacteria Exiguobacterium sp. showing best antimicrobial and antioxidant activities isolated from different regions of India. The Exiguobacterium sp. showed activity against Shigella, Klebsiellasp and Staphylococcus aureus. Similarly studies by Nisha et al., $(2019 a, b)$ has isolated and reported potential isolates with wide antibacterial activity namely Bacillus horikoshii and P.agglomerans from alfalfa plant rhizosphere regions.

Molecular characterization of the isolates: The study results of BLAST showed100\% similarity with Macrococcus equipercicus (Fig. 2 and 3 ) and the gene sequences were submitted to the Gene bank (NCBI, USA) and Genebank ID accession number MK240540 received.

GC-MS Analysis: About twenty five compounds were identified from Macrococcus equipercicus extract by using GC-MS (Fig. 4). Table 1 and 2 reveal the compounds molecular formula, weight, structure, mass spectra and compound nature and its activities.

The highest intensity (29.58) with retention time of 36.20 showed 13-Docosenamide compound, has 
Thasneem, Z. A. et al. / J. Appl. \& Nat. Sci. 11(3): 645- 649 (2019)

Table 1. Showing GCMS analysis of compounds obtained from Macrococcus equipercicus extract.

\begin{tabular}{|c|c|c|c|c|c|c|}
\hline S.N. & RT & Name of the compounds & Molecular formula & $\begin{array}{l}\text { Molecular } \\
\text { weight }\end{array}$ & Peak area & Compound structure \\
\hline 1 & 5.57 & Benzene 1,3,5-trimethyl & $C_{9} H_{12}$ & 120 & 2.71 & \\
\hline 2 & 8.16 & Dodecane & $\mathrm{C}_{12} \mathrm{H}_{26}$ & 170 & 3.30 & \\
\hline 3 & 9.18 & Memantine & $\mathrm{C}_{12} \mathrm{H}_{21} \mathrm{~N}$ & 179 & 4.42 & \\
\hline 4 & 10.40 & $\begin{array}{l}\text { 4-Cyano-2H-1- } \\
\text { benzothiopyran }\end{array}$ & $\mathrm{C}_{10} \mathrm{H}_{7} \mathrm{NS}$ & 173 & 5.22 & \\
\hline 5 & 11.29 & Tetradecane & $\mathrm{C}_{14} \mathrm{H}_{30}$ & 198 & 2.97 & \\
\hline 6 & 13.25 & $\begin{array}{l}\text { 2-tert-Butyl-4-isopropyl-5- } \\
\text { methylphenol }\end{array}$ & $\mathrm{C}_{14} \mathrm{H}_{22} \mathrm{O}$ & 206 & 2.36 & \\
\hline 7 & 13.70 & $\begin{array}{l}\text { 2-tert-Butyl-4-isopropyl-5- } \\
\text { methylphenol }\end{array}$ & $\mathrm{C}_{14} \mathrm{H}_{22} \mathrm{O}$ & 206 & 2.36 & \\
\hline 8 & 15.49 & Hexadecane & $C_{16} H_{34}$ & 226 & 2.23 & \\
\hline 9 & 15.72 & $\begin{array}{l}\text { 5,8,11-Heptadecatriynoic } \\
\text { acid,methyl ester }\end{array}$ & $\mathrm{C}_{18} \mathrm{H}_{24} \mathrm{O}_{2}$ & 272 & 1.65 & \\
\hline 10 & 19.14 & 1,4-dioxobicyclononane & $C_{7} H_{10} N_{2} O_{2}$ & 154 & 2.17 & \\
\hline 11 & 19.59 & 1-Hexadecanol & $C_{16} H_{34} O$ & 242 & 2.05 & \\
\hline 12 & 22.44 & $\begin{array}{l}\text { 1,4-diaza-2,5-dioxo-3- } \\
\text { isobutyl bicyclononane }\end{array}$ & $C_{11} H_{18} N_{2} O_{2}$ & 210 & 4.41 & \\
\hline 13 & 23.56 & $\begin{array}{l}\text { Hexadecanoicacid,ethyl } \\
\text { ester }\end{array}$ & $\mathrm{C}_{18} \mathrm{H}_{36} \mathrm{O}_{2}$ & 284 & 4.47 & \\
\hline 14 & 23.68 & $\begin{array}{l}\text { Hexadecanoic acid, ethyl } \\
\text { ester }\end{array}$ & $\mathrm{C}_{18} \mathrm{H}_{36} \mathrm{O}_{2}$ & 284 & 4.47 & \\
\hline 15 & 26.07 & $\begin{array}{l}\text { 2-Acetyl-3-ethyl-7- } \\
\text { methoxyindole }\end{array}$ & $\mathrm{C}_{22} \mathrm{H}_{22} \mathrm{~N}_{2} \mathrm{O}_{3}$ & 362 & 0.95 & \\
\hline 16 & 27.35 & $\begin{array}{l}\text { Octadecanoicacid,ethyl } \\
\text { ester }\end{array}$ & $\mathrm{C}_{20} \mathrm{H}_{40} \mathrm{O}_{2}$ & 312 & 3.15 & \\
\hline 17 & 27.47 & $\begin{array}{l}\text { Octadecanoic acid ,ethyl } \\
\text { ester }\end{array}$ & $\mathrm{C}_{20} \mathrm{H}_{40} \mathrm{O}_{2}$ & 312 & 3.15 & \\
\hline 18 & 29.57 & Ergotaman-3,6,18-trione & $C_{33} H_{35} N_{5} O_{5}$ & 581 & 2.83 & \\
\hline 19 & 30.12 & $\begin{array}{l}\text { Androst-4-en-3-one,17- } \\
\text { methoxy,3-methoxime }\end{array}$ & $\mathrm{C}_{21} \mathrm{H}_{33} \mathrm{NO}_{2}$ & 331 & 3.90 & \\
\hline 20 & 31.76 & Lucenin2 & $C_{27} H_{30} O_{16}$ & 610 & 0.63 & \\
\hline 21 & 32.45 & $\begin{array}{l}\text { 3,17-Dioxo-11-a- } \\
\text { hydroxyandrostane-1,4- } \\
\text { diene }\end{array}$ & $\mathrm{C}_{19} \mathrm{H}_{24} \mathrm{O}_{3}$ & 300 & 1.52 & \\
\hline 22 & 33.92 & $\begin{array}{l}\text { 3,17-Dioxo-11-a- } \\
\text { hydroxyandrostane-1,4- } \\
\text { diene }\end{array}$ & $\mathrm{C}_{19} \mathrm{H}_{24} \mathrm{O}_{3}$ & 300 & 1.52 & \\
\hline 23 & 36.20 & 13-Docosenamide & $\mathrm{C}_{22} \mathrm{H}_{43} \mathrm{NO}$ & 337 & 29.58 & \\
\hline 24 & 37.34 & $\begin{array}{l}\text { Tetracosa-2,6,14,18,22- } \\
\text { pentaene-10,11- } \\
\text { diol,2,6,10,15,19,23- } \\
\text { hexamethyl }\end{array}$ & $\mathrm{C}_{30} \mathrm{H}_{52} \mathrm{O}_{2}$ & 444 & 1.35 & = \\
\hline 25 & 37.72 & $\begin{array}{l}\text { QUERCETIN7,3,4- } \\
\text { TRIMETHOXY }\end{array}$ & $\mathrm{C}_{18} \mathrm{H}_{16} \mathrm{O}_{7}$ & 344 & 0.73 & 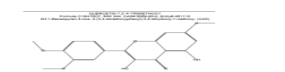 \\
\hline
\end{tabular}


Table 2. Activity of compounds identified in Macrococcus equipercicus extract.

\begin{tabular}{|c|c|c|c|c|}
\hline S.N. & RT & Name of the compound & Compound nature & Activity \\
\hline 1 & 5.57 & Benzene 1,3,5-trimethyl & Aromatic hydrocarbon & precursor to styrene \\
\hline 2 & 8.16 & Dodecane & Alkane hydrocarbon & Solvent \\
\hline 3 & 9.18 & Memantine & Amantidine & Treat Alzimer's disease \\
\hline 4 & 10.40 & $\begin{array}{l}\text { 4-Cyano-2H- } \\
\text { benzothiopyran }\end{array}$ & Aromatic compound & Used in drugs \\
\hline 5 & 11.29 & Tetradecane & Alkane hydrocarbon & Petroleum spirit \\
\hline 6 & 13.25 & $\begin{array}{l}\text { 2-tert-Butyl-4-isopropyl-5 } \\
\text {-metylphenol }\end{array}$ & $\begin{array}{l}\text { Lipophilic organic } \\
\text { compound }\end{array}$ & Food additive \\
\hline 7 & 13.70 & $\begin{array}{l}\text { 2-tert-Butyl-4-isopropyl-5 } \\
\text {-metylphenol }\end{array}$ & $\begin{array}{l}\text { Lipophilic organic } \\
\text { compound }\end{array}$ & Food additive \\
\hline 8 & 15.49 & Hexadecane & Alkane hydrocarbon & Fuel mixture \\
\hline 9 & 15.72 & $\begin{array}{l}5,8,11, \text { Heptadecatriynoic } \\
\text { acid methyl ester }\end{array}$ & Acid compounds & Explosive properties \\
\hline 10 & 19.14 & 1,4-dioxobicycloninane & Organic compound & Dehydrohalogenation \\
\hline 11 & 19.59 & 1-Hexadecanol & Fatty alcohol & Opacifier \\
\hline 12 & 22.44 & $\begin{array}{l}\text { 1,4-diaza-2,5-dioxo-3- } \\
\text { isobutyl bicyclononane }\end{array}$ & Not reported & Not reported \\
\hline 13 & 23.56 & $\begin{array}{l}\text { Hexadecanoic acid ethyl } \\
\text { ester }\end{array}$ & Saturated fatty acid & $\begin{array}{l}\text { antimicrobial, antioxidant, antifungal, } \\
\text { 5Alpha reductase inhibitor and hypo- } \\
\text { cholesterolemic }\end{array}$ \\
\hline 14 & 23.68 & $\begin{array}{l}\text { Hexadecanoic acid ethyl } \\
\text { ester }\end{array}$ & Saturated fatty acid & $\begin{array}{l}\text { antimicrobial, antioxidant, antifungal, } \\
\text { 5Alpha reductase inhibitor and hypo- } \\
\text { cholesterolemic }\end{array}$ \\
\hline 15 & 26.07 & $\begin{array}{l}\text { 2-Acetyl-3-ethyl-7- } \\
\text { methyoxyindole }\end{array}$ & Not reported & Transform Harman alkaloids \\
\hline 16 & 27.35 & $\begin{array}{l}\text { Octadecanoic acid ethyl } \\
\text { ester }\end{array}$ & Saturated fatty acid & Confers solubility in organic solvent \\
\hline 17 & 27.47 & $\begin{array}{l}\text { Octadecanoic acid ethyl } \\
\text { ester }\end{array}$ & Saturated fatty acid & Confers solubility in organic solvent \\
\hline 18 & 29.57 & Ergotaman-3,6,8-trione & Alkaloid & $\begin{array}{l}\text { Inhibits vesicular glutamate transporter } \\
\text { activity in cow cerebral synaptic vesi- } \\
\text { cles }\end{array}$ \\
\hline 19 & 30.12 & $\begin{array}{l}\text { Androst-4-eb-3-one,17- } \\
\text { methoxy,3-methoxime }\end{array}$ & Aromatic compound & $\begin{array}{l}\text { Aromatizing enzyme complex of human } \\
\text { placenta }\end{array}$ \\
\hline 20 & 31.76 & Lucenin2 & Glycosyl compound & Not reported \\
\hline 21 & 32.45 & $\begin{array}{l}\text { 3,17-Dioxo-11-a- } \\
\text { hydroxydrstane-1,4- } \\
\text { diene }\end{array}$ & Not reported & Not reported \\
\hline 22 & 33.92 & $\begin{array}{l}\text { 3,17-Dioxo-11-a- } \\
\text { hydroxydrstane-1,4- } \\
\text { diene }\end{array}$ & Not reported & Not reported \\
\hline 23 & 36.20 & 13-Docosenamide & $\begin{array}{l}\text { Amide of docosenoic } \\
\text { acid }\end{array}$ & $\begin{array}{l}\text { Reduces mobility and slightly lessened } \\
\text { awareness in cerebrospinal fluid of rat } \\
\text { and humam }\end{array}$ \\
\hline 24 & 37.34 & Tetracosa-2,6,14,18,22- & Not reported & Not reported \\
\hline
\end{tabular}

Antioxidant, anthelmintic, antimicrobial, antileishmanial, antiplasmodial

molecular formula is $\mathrm{C}_{22} \mathrm{H}_{43} \mathrm{NO}$ and molecular weight of 337 . The compound is amide of docosenoic acid, has been reported for Ludwigia perennis antimicrobial activity (Sharmila et al., 2017). The retention time of 4-Cyano-2Hbenzothiopyran from the microbial extract present at 10.40 and its peak area is 5.22 , has molecular formula as $C_{10} H_{7} N S$ and molecular weight is
173 and it is aromatic compound which has the activity in drug usage. The retention time of Androst-4-en-3-one,17-methoxy,3-methoxime is 30.12 and has peak area is 3.90 , has molecular formula is $\mathrm{C}_{21} \mathrm{H}_{33} \mathrm{NO}_{2}$ and molecular weight of 331 and it is an aromatic compound and it has an aromatizing enzyme complex of human placenta. Quercetin 7,3',4'-trimethyl ether is a trimethoxyflavone, derivative of quercetin. The compound 


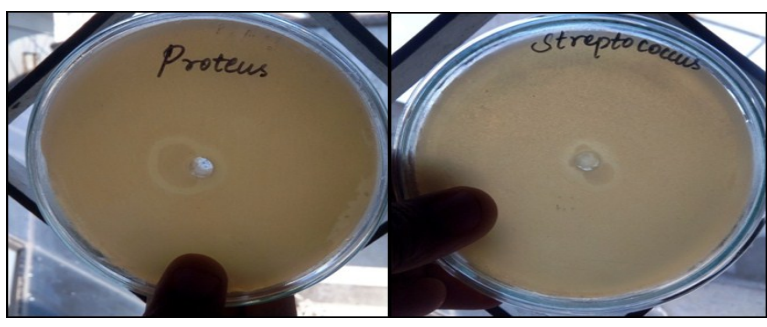

Fig. 1. Showing antibacterial activity of yellow pigmented colony against Streptococcus pneumonia and Proteus sp.

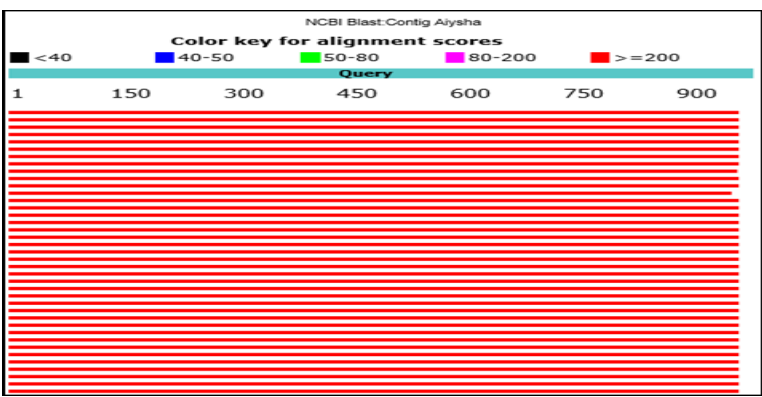

Fig. 2. Showing multiple alignment scores of Macrococcus equipercicus.

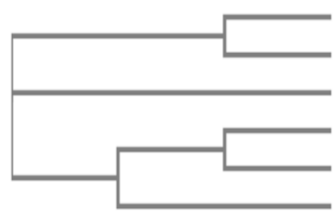

NR_036847.1_Macrococcus_brunensis Macrococcus equipercicus KP345966.1 Macrococcus sp. DQ279392.1_Micrococcus_sp AJ576067.1 Macrococcus equipercicus MG649989.1_Macrococcus_equipercicus

Fig. 3. Phylogenetic tree of Macrococcusequipercicus based on the 16S rRNA gene sequencing.

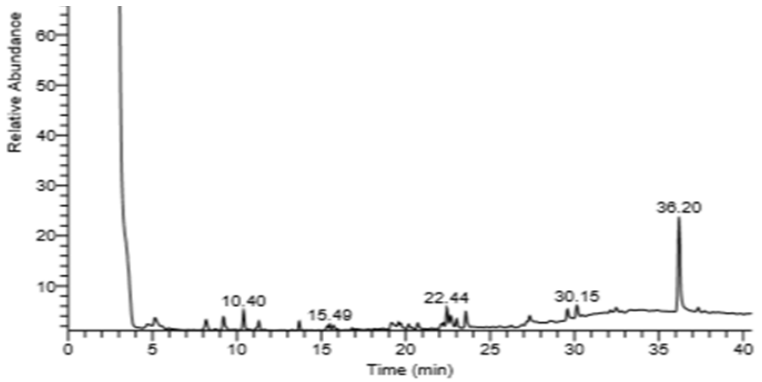

Fig. 4. GCMS spectrum analysis of Macrococcus equipercicus extract.

Quercetin 7,3,4-trimethoxy, a flavonoid has been reported for its activities such as antioxidant, anthelmintic, antimicrobial, antileishmanial, antiplasmodial by Kalpana Devi et al. (2016).

\section{Conclusion}

In present study, the soil isolate from the rhizosphere region of Alfalfa plant of Coimbatore was molecular characterized and identified with $100 \%$ similarity as Macrococcus equipercicus. Highest activity was recorded against two pathogens Streptococcus pneumonia and Proteus $s p$ which can be due to presence of 13-docosenamide at retention time of 36.2 minutes. In vitro and In vivo biological studies are further necessary to find new drugs against cancer. Through this study we were able to identify potent antimicrobial compounds such as memantine, quercetin and various esters from medicinally important Medicago sativa. Thus, the study provides insight into microflora and its bioactive compounds harbouring alfalfa rhizosphere soil region.

\section{REFERENCES}

1. Arora, S., Nandi, D., Prasad, N., Rawat, S. and Pandeya, A, (2013). Isolation and characterisation of antibiotic producing microbes present in rhizospheric soil. International Journal of Scientific \& Engineering Research, 4(9):1157-1166.

2. Becker, K., Heilmann, C., Peters, G. (2014). Coagulase-negative Staphylococci. Clinical Microbiology Revie, ws 27(4): 870 -926.

3. Bertin, C., Yang, X., and Weston, L. A. (2003). The role of root exudates and allelochemicals in the rhizosphere. Plant and Soil, 256(1): 67-83.

4. Bora, K. S., Anupam Sharma (2011). Phytochemical and pharmacological potential of Medicago sativa: A review. Pharma Biol.,49(2): 211-220.

5. Janani, B., Kiruthika, P., Angayarkanni, J. (2014). Isolation Of Pigmented Marine Bacteria Exiguobacterium Sp. From Peninsular Region Of India And A Study On Biological Activity Of Purified Pigment. International Journal of Scientific \& Technology Research, 3(3): 375-384

6. Kalpana Devi, R., Subramani, V., Annamalai, P., Nakulan, Vr., Narayanaperumal, J. (2016). Phytochemical analysis, in vitro antioxidant potential and gas chromatography-mass spectrometry studies of Dicranopterislinearis. Asian J. Pharm. Clin. Res., 9 (2): 220-225.DOI: http://dx.doi.org/10.22159/ ajpcr.2016.v9s2.13636

7. Krakowska, A., Ska, K.R., Walczak, J., Kowalkowski, T., Buszewsk, B. (2017). Comparison of Various Extraction Techniques of Medicago sativa: Yield, Antioxidant Activity, and Content of Phytochemical Constituents. J AOAC International, 100(6): 1681-93.doi: 10.5740/jaoacint.17-0234.

8. Nisha, M. Nair, Kanthasamy, R., Mahesh, R., IruthayaKalaiSelvam, S. and Ramalakshmi, S. (2019a). Identification of Antibacterial Compound from Bacillus horikoshii, isolated from rhizosphere region of Alfalfa plant. Journal of Applied Sciences, 19(2): 140147.DOI: 10.3923/jas.2019.140.147

9. Nisha, M. Nair, Kanthasamy, R., Mahesh, R., IruthayaKalaiSelvam, S. and Ramalakshmi, S. (2019b). Production and Characterization of Antimicrobials from isolate PantoeaAgglomerans of Alfalfa Plant Rhizosphere Soil. Journal of Applied and Natural Science, 11(2): 267-272.Doi: https:/l doi.org/10.31018/jans.v11i2.2031

10.Sharmila, M., Rajeswari, M., Jayashree, I. (2017). GC-MS Analysis of Bioactive Compounds in the Whole Plant of Ethanolic Extract of Ludwigiaperennis L. Int J Pharm Sci Rev Res 46(1): 124-128.

11.Zhang, L., Zhang, D., Feng, K. (2006). Inhibition of refined components of Medicago sativa polysaccharides to the activities of reverse transcriptase of HIV and protease of HIV. Zhongguo Shipin Xuebao, 6:562 